\title{
Complete inhibition of food-stimulated gastric acid secretion by combined application of pirenzepine and ranitidine*
}

\author{
W LONDONG, $\uparrow \mathrm{V}$ LONDONG, C RUTHE, AND P WEIZERT \\ From the Medizinische Klinik Innenstadt, University of Munich, Munich, W Germany
}

SUMMARY In a double-blind, placebo controlled and randomised secretory study the effectiveness of pirenzepine, ranitidine, and their combination was compared intraindividually in eight healthy subjects receiving intravenous bolus injections. Pirenzepine $(0 \cdot 15 \mathrm{mg} / \mathrm{kg})$ plus ranitidine $(0 \cdot 6$ $\mathrm{mg} / \mathrm{kg}$ ) suppressed peptone-stimulated gastric acid secretion from $69 \pm 11$ to $2 \pm 0 \cdot 4 \mathrm{mmol} \mathrm{H} / 3 \mathrm{~h}$; the mean percentage inhibition was $97 \%$. Postprandial gastrin was unaffected. There were only minor side-effects in a few experiments (reduction of salivation, brief blurring of vision), but no prolactin stimulation after ranitidine or ranitidine plus pirenzepine. The combined application of ranitidine and pirenzepine inhibited meal-stimulated acid secretion more effectively and produced fewer side-effects than the combination of cimetidine plus pirenzepine studied previously.

The combined application of classical anticholinergics and $\mathrm{H}_{2}$-receptor antagonists inhibits basal and stimulated gastric acid secretion in man more than either drug alone. ${ }^{1-6}$ In double-blind, placebo controlled and randomised investigations we have demonstrated $^{7-9}$ that combined intravenous bolus injections of the antimuscarinic drug pirenzepine with cimetidine suppressed peptone-stimulated acid output more effectively (on average by $90 \%$ ) than either drug alone. We concluded from our data that the 'optimal effective dose'10 of such an intravenous combination in man is $0 \cdot 15 \mathrm{mg} / \mathrm{kg}$ pirenzepine plus $1.5 \mathrm{mg} / \mathrm{kg}$ cimetidine, producing a mean percentage inhibition of $80 \%$ of peptone-stimulated acid secretion and a clear reduction of acute side-effects of both drugs. As the side-effects of cimetidine given as intravenous bolus (endogenous prolactin stimulation) could not be eliminated completely, additional experiments with the new competitive $\mathrm{H}_{2}$-blocker ranitidine seemed to be justified. We therefore studied the effects of the combination of pirenzepine plus ranitidine on peptone-stimulated gastric acid secretion, serum gastrin, serum prolactin, and sideeffects, monitored or specified by the subjects.

\footnotetext{
*These studies were presented in part at the International Congress of Gastroenterology, Hamburg, 8-13 June 1980.

tAddress for correspondence: $\mathrm{Dr}$ med Walter Londong, Medizinische Universitätsklinik Innenstadt, Ziemssenstraße 1, D-8000 München 2, W Germany.

Received for publication 15 January 1981
}

\section{Methods}

Each subject had four tests which had to be carried out within a fortnight; the interval between two tests was at least three days. On separate days each subject received pirenzepine, ranitidine, pirenzepine plus ranitidine, and placebo in random order by slow intravenous bolus on a double-blind basis according to a predetermined randomisation code. Injections were given by a physician not otherwise involved in the study. Eight healthy volunteers (four female, four male) with a mean age of 28 years (range 22-37 years), a mean body weight of $67 \mathrm{~kg}$ (range $56-84 \mathrm{~kg}$ ), and a mean height of $177 \mathrm{~cm}$ (range 160-195 cm) were studied. They had no history of upper abdominal disease, were not pregnant or breast-feeding, were not taking any concurrent medication, and had no persistent abnormality of haematology (haemoglobin concentration, haematocrit, white cell and platelet count, erythrocyte sedimentation rate), biochemistry (total bilirubin, transaminases, total protein and electrophoresis, prothrombin index, cholesterol, electrolytes, creatinine, urea-nitrogen, uric acid) or urine analysis screen (protein, sugar, urobilinogen, sediment).

The volunteers received $0.15 \mathrm{mg} / \mathrm{kg}$ pirenzepine and $0.6 \mathrm{mg} / \mathrm{kg}$ ranitidine intravenously given alone or in combination. The ranitidine dose was chosen according to Hagenmüller et al. ${ }^{11}$ who demonstrated that $40 \mathrm{mg}$ ranitidine were equipotent to $200 \mathrm{mg}$ 
cimetidine intravenously. Bolus injections of isotonic saline were used as placebo. The study was approved by the Ethical Committee of the Medical Faculty of the University of Munich. All volunteers gave written consent to participation in this study after full explanation by the investigator.

Peptone-stimulated gastric acid secretion of the volunteers who had fasted overnight was measured by an in vivo intragastric titration method according to Fordtran and Walsh ${ }^{12}$ modified by Becker ${ }^{13}$ using an automatic combititrator (Deutsche Metrohm GmbH \& Co, Filderstadt, FRG) for titration with $1 \mathrm{~N}$ sodium hydroxide with the end point of $\mathrm{pH} 5.5$. The intragastric stimulus was a $10 \%$ aqueous solution of Bactopeptone (Difco Laboratories, Detroit/Michigan, USA) which was adjusted to $\mathrm{pH} 5.5$ before intragastric instillation and circulation through the stomach via a double-luminal gastric tube (Levinetype Ch 16) by a peristaltic pump (Blutpumpe BP 742 from Fresenius Apparatebau, Bad Homburg, FRG) with an average speed of $280 \mathrm{ml} / \mathrm{min}$. Continuous titration with monitoring of sodium hydroxide consumption at five minute intervals was carried out in all subjects lying in a left-lateral position and spitting out their saliva during the whole secretory study. Acid outputs were expressed as mmol $\mathrm{H}^{+}$per 15 minutes and calculated as $\mathrm{mmol} \mathrm{H}^{+}$per three hours. At the beginning of each secretory study $300 \mathrm{ml}$ of peptone solution were instilled via tube into the stomach. Losses of peptone solution via the pylorus were corrected during the test procedure. At the end of each test gastric volumes were aspirated completely.

Before the start of each study an intravenous cannula was inserted into a forearm vein and isotonic saline infused at $60 \mathrm{ml} / \mathrm{h}$ to keep the line patent. Fasting blood samples were taken at 0 and 15 minutes, after swallowing the tube at $\mathbf{3 0}$ minutes (before the start of intragastric titration of peptone-stimulated acid output), and then every 15 minutes during the test procedure. The intravenous bolus was injected via the cannula at 70 minutes - that is, 40 minutes after the start of intragastric titration when acid output had nearly reached a sustained plateau. The blood samples were cooled on ice before centrifugation. All the deep-frozen sera from the four different secretory studies of one volunteer were thawed at the same time and analysed in the same assay. Serum gastrin was estimated by our radioimmunoassay ${ }^{14}$ using the specific rabbit antibody 4562 which detects component I, big (G 34), little (G 17), and mini gastrin (G 14) in nearly equimolar potency ${ }^{15}$ using synthetic human gastrin I (MRC) as standard and a doubleantibody as technique for separation of bound and free. The lower limit of detection is less than $2 \mathrm{pg} / \mathrm{ml}$. Radioimmunological measurements of serum prolactin were performed using a specific antibody against human serum prolactin. ${ }^{16}$ This assay has a lower detection limit of less than $20 \mu \mathrm{U} / \mathrm{ml}$. The quality control of both assays equal those of international standards.

Side-effects were monitored by the subjects during and after the secretory studies and also by careful observation of the volunteers during the test by the investigator. Peripheral pulse rate was counted at five minutes before and at two, seven, 15, 60, 120, and 180 minutes after the intravenous bolus. Only after the secretory studies were completed in all volunteers, was the randomisation code broken and the data evaluated. Statistical analysis was done using Wilcoxon matched pairs signed rank test. Only $P$ values less than 0.01 were considered to be significant (two-tail reading).

\section{Results}

Acid secretion showed an excellent reproducibility during the stimulatory phase from 30 to 70 minutes before single or combined application of the drugs at 70 minutes (Fig. 1). The pronounced inhibitory effects of both drugs or their combination occurred within 20 minutes after the bolus injection. Pirenzepine had the weakest effect, and this seemed to be relatively stable throughout the test period. Compared with placebo its inhibition was significant within 35 minutes after drug injection and lasted from 105 to 240 minutes. The inhibitory effect of ranitidine was stronger, being significant within 20 minutes after intravenous bolus, and lasted from 90 to 255 minutes, although its effect wore off during the course of the test. The effects of pirenzepine and ranitidine were therefore significantly different only from 105 to 135 minutes. The combination showed a more drastic reduction of stimulated acid output; within five minutes after the bolus injection significant differences from placebo were noted (75 to 255 minutes). The differences versus ranitidine were significant from 135 to 255 minutes, when a rather stable and practically complete inhibition of peptone-stimulated acid secretion to mean values ( $\overline{\mathrm{x}} \pm \mathrm{SEM}$ ) of $0 \cdot 01 \pm 0 \cdot 01$ mmol $\mathrm{H}^{+} / 15 \mathrm{~min}$ (at 150 minutes) and $0 \cdot 2 \pm 0 \cdot 1 \mathrm{mmol}$ $\mathrm{H}^{+} / 15$ min (at 240 and 255 minutes) was established.

Fasting serum gastrin values were well reproducible at the beginning of the four tests (mean of all four tests at 30 minutes: $42 \mathrm{pg} / \mathrm{ml}$ ). After intragastric instillation of peptone solution there was a significant increase to about $125 \mathrm{pg} / \mathrm{ml}$ (mean of all four tests at 45 minutes). During the secretory studies gastrin values remained raised and were not altered by the two drugs or their combination.

The histograms of calculated acid output per 3 hours (75 to 255 minutes of the test period) (Fig. 2) demonstrate the marked inhibitory effect of the com- 
Fig. 1 Effect of placebo, pirenzepine, ranitidine, and their combination (in same doses) given as slow intravenous bolus injection on peptone-stimulated gastric acid secretion and serum gastrin in eight healthy volunteers (mean $\pm S E M$ ). Asterisks indicate significant differences $(\mathrm{P}<0.01)$ between the effects of combined application and ranitidine alone.

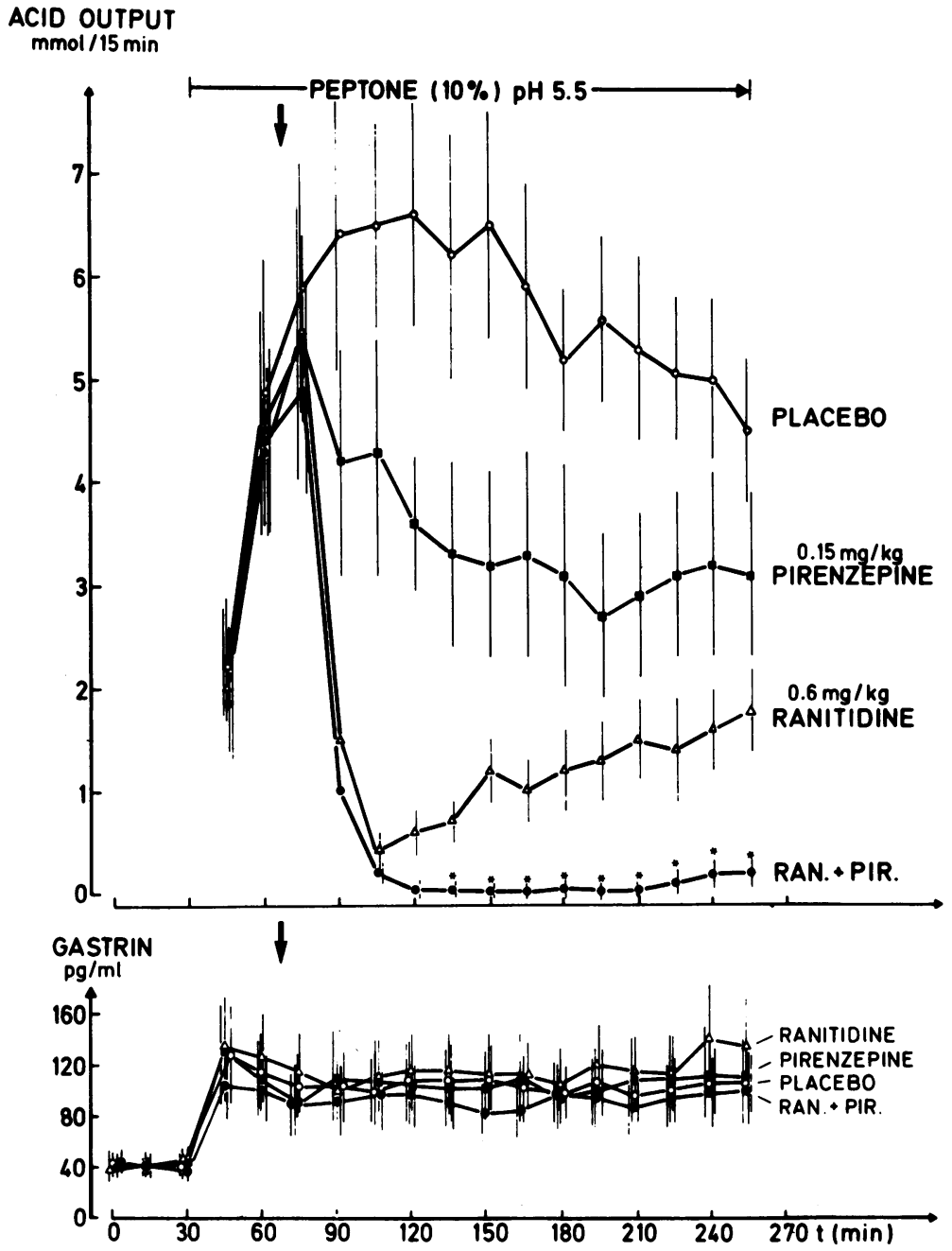

bined application of pirenzepine and ranitidine. Mean stimulated acid output per three hours $\left(\overline{\mathrm{x}} \pm\right.$ SEM) was reduced from $68.8 \pm 11.0 \mathrm{mmol} \mathrm{H}^{+}$ (placebo) to $40.0 \pm 11.0 \mathrm{mmol} \mathrm{H} \mathrm{H}^{+}$by $0.15 \mathrm{mg} / \mathrm{kg}$ pirenzepine, to $14 \cdot 1 \pm 3.5 \mathrm{mmol} \mathrm{H}^{+}$by $0.6 \mathrm{mg} / \mathrm{kg}$ ranitidine and to $1.9 \pm 0.4 \mathrm{mmol} \mathrm{H}^{+}$by their combination. The mean percentage inhibition was $42 \%$ by pirenzepine, $80 \%$ by ranitidine, and $97 \%$ by pirenzepine plus ranitidine.

The serum concentrations of prolactin (Fig. 3) were drawn as median because of a rather great variance between individuals tested. All subjects had normal basal values which declined continually during the first 90 minutes of the investigations, but were not altered by injections, either by pirenzepine or ranitidine alone or by their combination.
Table 1 summarises the side-effects that were reported. Reduction of salivation occurred more often after the combination (five times) than after pirenzepine (three times) or ranitidine (once). Brief blurring of vision occurred only once after the combination. Two subjects complained of palpitations for a few minutes directly after the injection of pirenzepine and one after the combination, although there were no increases of peripheral pulse rates. Other unspecific side-effects were mild diarrhoea or loose stools in the afternoon of the test day or transient nausea and desire to urinate during the secretory studies. On average a total of $590 \mathrm{ml}$ of $10 \%$ aqueous peptone solution was required during the secretory studies to maintain a constant speed of circulation for an exact titration of stimulated acid output. A mean 
Table 1 Side-effects volunteered by the subjects during and after the secretory studies

\begin{tabular}{lllll}
\hline & $\begin{array}{l}\text { Ranitidine } \\
0 \cdot 6 \\
(\mathrm{mg} / \mathrm{kg})\end{array}$ & $\begin{array}{l}\text { Pirenzepine } \\
0 \cdot 15 \\
(\mathrm{mg} / \mathrm{kg})\end{array}$ & $\begin{array}{l}\text { Ran. }+ \text { Pir. } \\
0 \cdot 6+0 \cdot 15 \\
(\mathrm{mg} / \mathrm{kg})\end{array}$ & Placebo \\
\hline $\begin{array}{llll}\text { Reduction of } \\
\text { Salivation }\end{array}$ & $1 / 8$ & $3 / 8$ & $5 / 8$ & $1 / 8$ \\
Blurred vision & $0 / 8$ & $0 / 8$ & $1 / 8$ & $0 / 8$ \\
Palpitations & $0 / 8$ & $2 / 8$ & $1 / 8$ & $0 / 8$ \\
Diarrhoea & $1 / 8$ & $3 / 8$ & $1 / 8$ & $0 / 8$ \\
$\begin{array}{l}\text { Others: nausea, desire } \\
\text { to urinate }\end{array}$ & $2 / 8$ & $1 / 8$ & $2 / 8$ & $1 / 8$ \\
\hline
\end{tabular}

of $460 \mathrm{ml}$ of gastric volume was aspirated at the end of the tests. There was no correlation between the different drug injection and the consumption of peptone solution.

The mean peripheral arterial pulse rates counted before and at definite intervals after bolus injections are shown in Table 2. After ranitidine there were no significant alterations compared with placebo, whereas pulse rates increased $(P<0.05)$ at two minutes after injection of pirenzepine. After pirenzepine alone and in combination the pulse rates decreased slightly at one, two, and three hours after the bolus injection. At two hours after the injection the difference between pulse rates after pirenzepine plus ranitidine and ranitidine alone was statistically significant $(\mathrm{P}<0 \cdot 01)$.

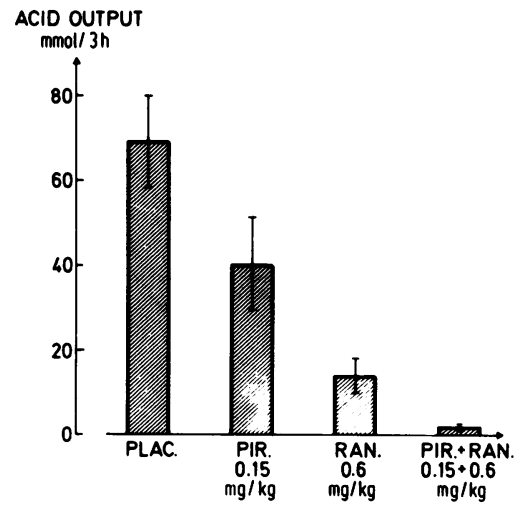

Fig. 2 Histograms of peptone-stimulated gastric acid secretion per three hours (mean $\pm S E M$ ) in eight healthy volunteers receiving placebo, $0.15 \mathrm{mg} / \mathrm{kg}$ pirenzepine, 0.6 $\mathrm{mg} / \mathrm{kg}$ ranitidine, and their combination (in same doses) as slow intravenous bolus injection.

\section{Discussion}

These experiments have shown that combined intravenous bolus injection of the antimuscarinic drug pirenzepine and the new $\mathrm{H}_{2}$-receptor antagonist ranitidine inhibits food-stimulated gastric acid secretion in man by $97 \%$ and for more than three hours.

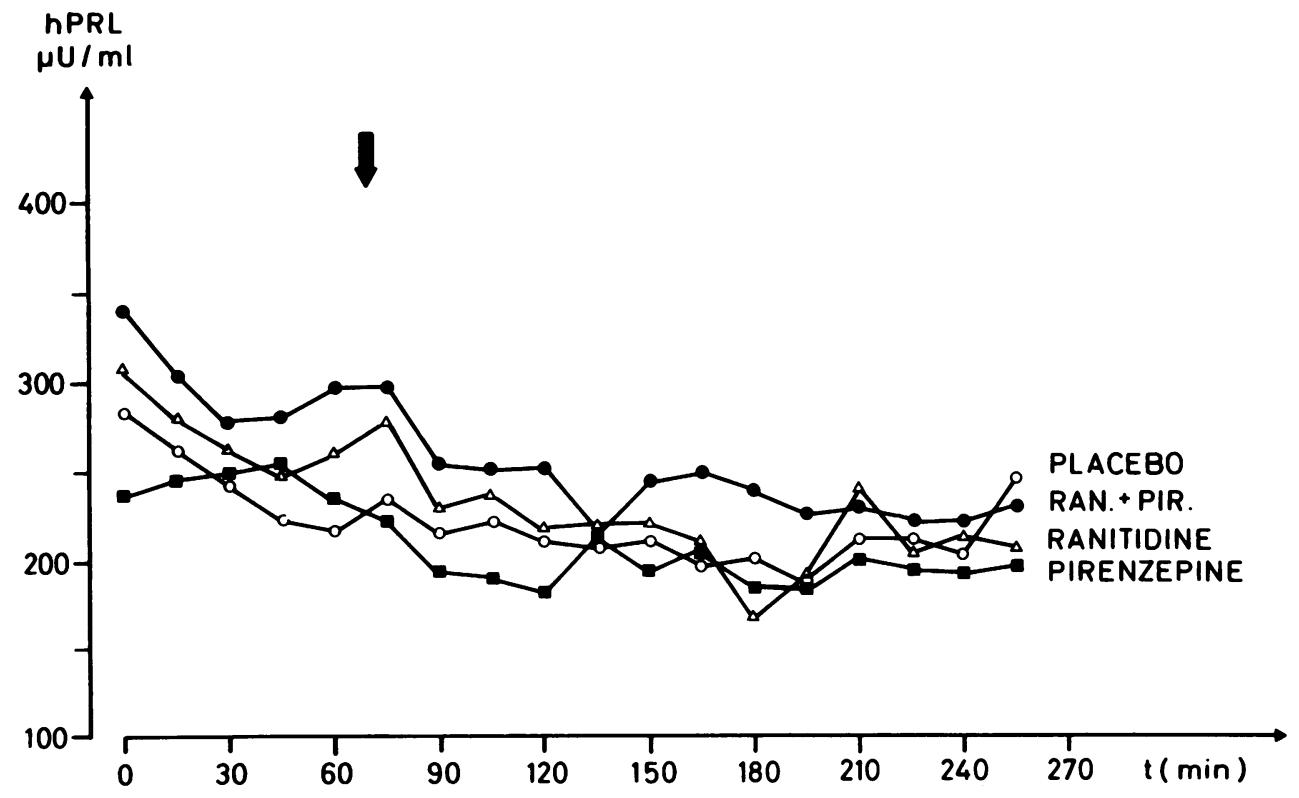

Fig. 3 Serum concentrations of median prolactin ( $h P R L)$ in eight healthy volunteers receiving placebo, pirenzepine, ranitidine, and their combination as slow intravenous bolus injection (for doses see legend of Fig. 2). 
Table 2 Peripheral pulse rates in minutes $(\bar{x} \pm S E M)$ before and after intravenous bolus injection

\begin{tabular}{|c|c|c|c|c|c|c|c|}
\hline & \multirow{2}{*}{$\frac{\text { Before (min) }}{2}$} & \multicolumn{6}{|c|}{ After intravenous bolus injection (min) } \\
\hline & & 2 & 7 & 15 & 60 & 120 & 180 \\
\hline Placebo & $68 \pm 2$ & $66 \pm 3$ & $64 \pm 2$ & $62 \pm 3$ & $66 \pm 2$ & $69 \pm 3$ & $69 \pm 3$ \\
\hline Pirenzepine $(0 \cdot 15 \mathrm{mg} / \mathrm{kg})$ & $67 \pm 3$ & $73 \pm 3^{*}$ & $66 \pm 4$ & $64 \pm 4$ & $61 \pm 3+$ & $64 \pm 3$ & $62 \pm 2+$ \\
\hline Ranitidine $(0.6 \mathrm{mg} / \mathrm{kg})$ & $65 \pm 3$ & $67 \pm 4$ & $65 \pm 3$ & $64 \pm 3$ & $68 \pm 3$ & $68 \pm 3$ & $68 \pm 3$ \\
\hline Pirenzepine + ranitidine (same doses) & $64 \pm 2$ & $68 \pm 2$ & $65 \pm 2$ & $64 \pm 2$ & $61 \pm 2+$ & $59 \pm 3^{*} \ddagger$ & $62 \pm 2+$ \\
\hline
\end{tabular}

${ }^{*} \mathrm{P}<0.05$ versus placebo, ${ }_{\mathrm{P}}^{\mathrm{P}}<0.05$ versus ranitidine. $\ddagger_{\mathrm{P}}<0 \cdot 01$ versus ranitidine.

This complete inhibitory effect was even more pronounced than those achieved previously ${ }^{7-9}$ with combinations of pirenzepine $(0.075$ to $0.3 \mathrm{mg} / \mathrm{kg})$ and cimetidine $(1.5$ to $3.0 \mathrm{mg} / \mathrm{kg})$ which suppressed foodstimulated gastric acid secretion in healthy volunteers and patients with duodenal ulcer and gastric hypersecretion by 80 to $90 \%$. Except in one study ${ }^{49}$ such marked reductions have not been established with combinations of $\mathbf{H}_{2}$-receptor antagonists (metiamide or cimetidine) and conventional anticholinergic drugs (poldine, propantheline, $\mathrm{etc}^{1-6}$ ). An explanation for this difference seems to be that pirenzepine is a more selective antimuscarinic drug on parietal cell function than conventional anticholinergic drugs, which have very similar binding affinities to muscarinic receptors in different organ $s^{17}$ and therefore produce a number of unpleasant side-effects, which set limits to their clinical use. By contrast, pirenzepine distinguishes between different subclasses of muscarinic receptors and has low-affinity binding in smooth muscle and heart, but high affinity sites in exocrine glands. ${ }^{18}$

It is not clear whether the drastic reduction of acid secretion by the combination of pirenzepine and ranitidine is of any clinical relevance. Ranitidine inhibits pentagastrin-stimulated gastric acid secretion in a dose-dependent manner - that is, high doses of ranitidine alone abolish stimulated acid output in man. ${ }^{19-21}$ Such complete inhibition cannot be achieved by increasing the cimetidine dose. It was shown that doubling the normal oral dose does increase cimetidine blood levels, but does not reduce food-stimulated ${ }^{22}$ or nocturnal acid secretion ${ }^{23}$ to a greater extent nor does it increase ulcer healing. ${ }^{24}$ The duration of action on peptone-stimulated acid output of $0.6 \mathrm{mg} / \mathrm{kg}$ ranitidine given as an intravenous bolus in this study is comparable with that of 3.0 $\mathrm{mg} / \mathrm{kg}$ cimetidine in our previous investigations, ${ }^{79}$ and those of Sewing et al. ${ }^{25}$ However, the effect of 0.6 $\mathrm{mg} / \mathrm{kg}$ ranitidine intravenously is more potent, resulting in a mean percentage inhibition of $80 \%$ compared with $60 \%$ by $3.0 \mathrm{mg} / \mathrm{kg}$ cimetidine intravenously ${ }^{7}$ that is, ranitidine, in our model of meal-stimulated gastric acid secretion, is more than four to five times more potent on a molar basis than cimetidine. ${ }^{26}$

With present and previous acute experiments in man neither cimetidine,${ }^{7927}$ ranitidine, ${ }^{28}$ nor pirenzepine, ${ }^{7929}$ either alone or in combination, significantly alter postprandial gastrin. From these investigations with specific receptor antagonists it might be concluded that neither $\mathrm{H}_{2}$ - nor muscarinic receptors are important for food-stimulated gastrin release. Konturek et $a l .{ }^{26}$ have recently pointed out differences between atropine and pirenzepine on shamfeeding induced gastrin responses as well.

Previous studies with increasing intravenous bolus injections in man showed that pirenzepine-in contrast with other tricyclic compounds ${ }^{30}$ - had no stimulatory effects on serum prolactin. ${ }^{7}$ In our study bolus injections of ranitidine-in contrast with cimetidine $^{79}$ - had no prolactin stimulatory action. From experiments in rats it is known that cimetidine is an antiandrogen, ${ }^{31}$ whereas ranitidine is not. ${ }^{32}$ It is possible that high peaks of blood concentrations of cimetidine may relate to its antiandrogenic properties. ${ }^{313334}$

Reduction of salivation, which occurred mainly after pirenzepine alone or in combination, and brief blurred vision were weak and tolerable side-effects. In previous investigations ${ }^{9}$ dryness of the mouth occurred as often after $3.0 \mathrm{mg} / \mathrm{kg}$ cimetidine as after $0.3 \mathrm{mg} / \mathrm{kg}$ pirenzepine - that is, ranitidine caused this symptom less frequently than cimetidine. Palpitations were noticed by a few volunteers, but these subjects did not have any alteration of peripheral pulse rate, and, in particular, no tachycardia. However, there had been a slight and short-lasting mean increase two minutes after intravenous bolus of pirenzepine alone and a decrease at one, two, and three hours after pirenzepine alone and in combination. At two hours after combination this decrease was significant $(P<0.01)$. Ranitidine alone had no such effect on pulse rate, as already reported. ${ }^{21}$ The other sideeffects cannot be attributed to the drugs administered. Mild diarrhoea or loose stools at the afternoon of the secretory study may occur as a consequence of losses of hypertonic peptone solution via the pylorus 
(on average about $10 \%$ of all subjects investigated). Tolerable nausea is related to the gastric tube, and the desire to urinate could be due to the test lasting nearly five hours.

Significant decreases of heart rate have been reported after parenteral ${ }^{35}$ or high oral $^{36}$ doses of pirenzepine. This effect contrasts with cardiac effects of conventional anticholinergics and is hard to interpret, as pirenzepine was shown to have low affinity sites in the heart. ${ }^{18}$ Nevertheless, there are experimental data that pirenzepine may act in part by sympathetic mechanisms. ${ }^{37}$ Recently, direct binding studies demonstrated muscarinic receptors in sympathetic ganglia which were characterised by high affinity pirenzepine binding. ${ }^{38}$

In our previous papers ${ }^{79}$ the possible clinical aspects of a combined application of cimetidine and pirenzepine were discussed in detail. Its clinical relevance is under trial in high-risk patients after bleeding from mucosal lesions stopped by lasercoagulation. As the combination of pirenzepine and ranitidine showed a stronger antisecretory effect and fewer side-effects, its clinical applicability should be studied, too. We agree with Langman et al. ${ }^{39}$ : 'The choice between the drugs in treating duodenal ulcer is likely to be influenced by their proneness to cause adverse effects rather than by their effect on healing'. In this respect it has to be pointed out that a complete inhibition of food-stimulated gastric acid secretion by combined application of muscarinic and $\mathrm{H}_{2}$-receptor antagonists might induce bacterial overgrowth of gastric flora and its potentially dangerous consequences. ${ }^{40}$ Therefore, such a combination should be applied only as short-term treatment in definable patients with complicated peptic ulcer disease. ${ }^{79}$

We are very grateful to Professor Dr J F Rehfeld, Aarhus/Denmark, and to Professor $\operatorname{Dr} \mathrm{K}$ von Werder, Endocrinological Department of our clinic, for providing us with their excellent antibodies.

\section{References}

'Barbezat GO, Bank S. Effect of histamine- $\mathrm{H}_{2}$-receptorantagonist and an anticholinergic on gastric acid secretion in man. $S$ Afr med J 1976; 50: 849-51.

${ }^{2}$ Feldman M, Richardson CT, Peterson WL, Walsh JH, Fordtran JS. Effect of low-dose propanetheline on foodstimulated gastric acid secretion. N Engl J Med 1977; 26: 1427-30.

${ }^{3}$ Richardson CT, Bailey BA, Walsh JH, Fordtran JS. The effect of an $\mathbf{H}_{2}$-receptor-antagonist on food-stimulated acid secretion, serum gastrin, and gastric emptying in patients with duodenal ulcer. J Clin Invest 1974; 55: 536-42.
${ }^{4}$ Saunders JHB, Cargill JM, Wormsley KG. Effects of cimetidine and poldine on nocturnal gastric secretion in duodenal ulcer. Digestion 1977; 15: 452-6.

sScholten Th, Fritsch WP, Müller JE. Hengels KJ. Langzeitsuppression der $\mathrm{H}^{+}$-Sekretion durch Kombination von Cimetidine und Methanthelinbromid. Dtsch med Wschr 1979; 104: 1849-53.

${ }^{6}$ Thjodleifsson B, Wormsley KG. Gastric response to metiamide. Br Med J 1974; 2: 304-6.

${ }^{7}$ Londong W, Londong V, Prechtl R, Eversmann $T$. Vergleichende Untersuchungen der Pirenzepin- und Cimetidinwirkung auf Pepton-stimulierte Säuresekretion und Serumgastrin des Menschen. In: Blum AL, Hammer $\mathrm{R}$, eds. Die Behandlung des Ulcus pepticum mit Pirenzepin. Gräfelfing: Demeter-Verlag, 1979: 75-82.

${ }^{8}$ Londong W, Londong V, Weber Th, von Werder $\mathrm{K}$. Interaction of an antimuscarinic and an $\mathbf{H}_{\mathbf{2}}$-receptor antagonising drug in man. Gut 1980; 21A: 451.

${ }^{9}$ Londong W, Londong V, Prechtl R, Weber Th, von Werder $\mathrm{K}$. Interactions of cimetidine and pirenzepine on peptone-stimulated gastric acid secretion in man. Scand $J$ Gastroenterol 1980; 15: suppl 66: 103-112.

${ }^{10}$ Sun DCH, Shay H. Optimal effective dose of anticholinergic drug in peptic ulcer therapy. Arch Intern Med 1956; 97: 442-52.

${ }^{11}$ Hagenmüller F, Zeitler-Abu-Ishira A, Classen $\mathbf{M}$. Hemmung der Magensäuresekretion durch den Histamin$\mathrm{H}_{2}$-Rezeptorantagonisten AH 19065 (Ranitidine) im Vergleich zu Cimetidine-eine Doppelblindstudie. $Z$ Gastroenterol 1979; 17: 583.

${ }^{12}$ Fordtran JS, Walsh JH. Gastric acid secretion rate and buffer content of the stomach after eating: results in normal subjects and in patients with duodenal ulcer. $J$ Clin Invest 1973; 52: 645-57.

${ }^{13}$ Becker HD. Methodischer Fortschritt in der Funktionsdiagnostik des Magens: Magensekretionsanalyse, intragastrale Titration, endokrine Provokationstests. $Z$ Gastroenterol 1978; 16: 118-25.

${ }^{14}$ Londong W, Geier E, Feifel G, Forell MM. Hypoglykämieinduzierte Gastrinfreisetzung nach Vagotomie. Z Gastroenterol 1975; 13: 418-23.

${ }^{15}$ de Magistris L, Rehfeld JF. A simple enzymatic procedure for radioimmunochemical quantitation of the large molecular forms of gastrin and cholecystokinin. Anal Biochem 1980; 102: 126-33.

${ }^{16}$ von Werder K, Felixberger F, Gottsmann M, Kerner W, Glöckner B. A homologous human prolactin (hPRL) radioimmunoassay with an antibody against 'little' hPRL. In: Radioimmunoassay and related procedures in medicine. Vienna: Intern Atomic Energy Agency 1978: 43-54.

${ }^{17}$ Ariens EJ, Beld AJ, Rodrigues de Miranda JF, Simonis AM. The pharmacon-receptor-effector concept: a basis for understanding the transmission of information in biological systems. In: O'Brian RD, ed. The receptors. New York: Plenum Press, 33-91.

${ }^{18}$ Hammer R, Berrie CP, Birdsall NJM, Burgen ASV, Hulme EC. Pirenzepine distinguishes between different subclasses of muscarinic receptors. Nature 1980; 283: 90-2.

${ }^{19}$ Domschke W, Lux G, Domschke S. Gastric inhibitory action of $\mathrm{H}_{2}$-antagonists ranitidine and cimetidine. Lancet 1979; 1: 320.

${ }^{20}$ Simon B, Kather H. Hemmung der Pentagastrin- 
stimulierten Magensekretion durch Ranitidin. Dtsch med Wschr 1979; 104: 1676-8.

${ }^{21}$ Woodings EP, Dixon GT, Harrison C, Carey P, Richards DA. Ranitidine-a new $\mathbf{H}_{\mathbf{2}}$-receptor antagonist. Gut 1980; 21: 187-91.

${ }^{22}$ Pounder RE, Williams JG, Hunt RH, Vincent SH, Milton-Thompson GJ, Misiewicz JJ. The effects of oral cimetidine on food-stimulated gastric acid secretion and 24-hour intragastric acidity. In: Burland WL, Alison Simkins M, eds. Cimetidine. Amsterdam: Excerpta Medica, 1977; 189-204.

${ }^{23}$ Blackwood WS, Northfield TC. Nocturnal gastric acid secretion: effect of cimetidine and interaction with anticholinergics. In: Burland WL, Alison Simkins M, eds. Cimetidine. Amsterdam: Excerpta Medica, 1977: 124-30.

${ }^{24}$ Multicentre Trial. Comparison of two doses of cimetidine and placebo in the treatment of duodenal ulcer. Gut 1979; 20: 68-74.

${ }^{25}$ Sewing K-Fr, Billian A, Malchow H. Comparative study of ranitidine and cimetidine on gastric secretion in normal volunteers. Gut 1980; 21: 750-2.

${ }^{26}$ Konturek SJ, Obtulowicz W, Kwiecień N, Dobrzańska M, Swierczek J, Knopp B, Oleksy J. Effects of pirenzepine and atropine on gastric secretory and plasma hormonal responses to sham-feeding in patients with duodenal ulcer. Scand J Gastroenterol 1980; 15: suppl 66: 63-69.

${ }^{27}$ Longstreth GF, Malagelada JR, Go VLW. Postprandial gastric, pancreatic, and biliary response to histamine $\mathrm{H}_{2}$ receptor antagonist in active duodenal ulcer. Gastroenterology 1977; 72: 9-13.

${ }^{28}$ Konturek SJ, Obtulowicz W, Kwiecień N, Sito E, Mikos $\mathrm{E}$, Oleksy J. Comparison of ranitidine and cimetidine in the inhibition of histamine, sham-feeding, and mealinduced gastric secretion in duodenal ulcer patients. Gut 1980; 21 : 181-6.

${ }^{29}$ El-Sabbagh HN, Bloom SR, Adrian TE, Prinz RA, Baron JH, Welbourn RB. The effect of pirzenzepine on mealstimulated gastrointestinal hormones. Scand J Gastroenterol 1980; 15: suppl 66: 57-61.

${ }^{30}$ Kleinberg DL, Noel GL, Frantz AF. Chlorpromazine stimulation and L-dopa suppression of plasma prolactin in man. J Clin Endocrinol Metab 1971; 33: 873-6.

${ }^{31}$ Winters SJ, Banks JL, Loriaux DL. Cimetidine is an antiandrogen in the rat. Gastroenterology 1979; 76: 504-8.

${ }^{32}$ Brittain RT, Daly MJ. A review of the animal pharmacology of ranitidine-a new selective histamine $\mathrm{H}_{2}$-antagonist. Drug Symposium on Ranitidine, IV European Congress of Gastrointestinal Endoscopy, 14th June 1980, Hamburg.

${ }^{33}$ Gräf $\mathrm{KJ}$, von Kleist D, Meyer zum Büschenfelde $\mathrm{KH}$. Different effects of two histamine $\mathrm{H}_{2}$-receptor antagonists on prolactin secretion in man. Acta Endocr $(\mathrm{Kbh})$ suppl 234, $94: 4$.

${ }^{34}$ Spence RW, Celestin LR. Gynaecomastia associated with cimetidine. Gut 1979; 20: 154-7.

${ }^{35}$ Stacher G, Steinringer H, Bauer P, Ehn I, Schmierer G. Die Wirkung von intramuskulärem Pirzenzepin, Atropin und Placebo auf die mahlzeitstimulierte Motilität des Kolons. Eine Doppelblindstudie. In: Blum AL, Hammer $\mathrm{R}$, eds. Die Behandlung des Ulcus pepticum mit Pirenzepin. Gräfelfing: Demeter Verlag, 1979: 139-44.

${ }^{36}$ Fink M, Irwin P. EEG and behavioral effects of pirenzepine in normal volunteers. Scand J Gastroenterol 1980; 15: suppl 66: 39-46.

${ }^{37}$ Kitagawa H, Kurahashi K, Fijiwara M, Kohei H. Antiulcerogenic effect of a pyrido-benzodiazepine derivative (L-S 519) on experimental ulcers. Arzneim Forsch 1978; 28: 2122-7.

${ }^{38}$ Hammer R. Muscarinic receptors in the stomach. Scand J Gastroenterol 1980; 15: suppl 66: 5-12.

${ }^{39}$ Langman MJS, Henry DA, Bell GC, Burnham WR, Ogilvy A. Cimetidine and ranitidine in duodenal ulcer. $\mathrm{Br}$ Med J 1980; 281: 473-4.

${ }^{40}$ Ruddell WSJ, Axon ATR, Findlay JM, Bartholomew BA, Hill MJ. Effect of cimetidine on the gastric bacterial flora. Lancet 1980; 1: 672-4.

${ }^{41}$ Richardson CT, Bailey BA, Walsh JH, Fordtran JS. The effect of an $\mathrm{H}_{2}$-receptor antagonist on food-stimulated acid secretion, serum gastrin, and gastric emptying in patients with duodenal ulcer. J Clin Invest 1975; 55: 536-42. 